\title{
Hydrodynamic modelling of snapper Pagrus auratus egg and larval dispersal in Shark Bay, Western Australia: reproductive isolation at a fine spatial scale
}

\author{
Elizabeth L. Nahas ${ }^{1}$, Gary Jackson ${ }^{2}$, Charitha B. Pattiaratchi ${ }^{1, *}$, Gregory N. Ivey ${ }^{1}$ \\ ${ }^{1}$ Centre for Water Research, University of Western Australia, 35 Stirling Highway, Crawley, Western Australia 6009, Australia \\ ${ }^{2}$ Western Australian Marine Research Laboratories, PO Box 20, North Beach, Western Australia 6920, Australia
}

\begin{abstract}
Ichthyoplankton data collected between 1997 and 2000 were combined with the results of numerical modelling to investigate the dispersal of snapper Pagrus auratus eggs and larvae in Shark Bay, Western Australia. A 3-dimensional hydrodynamic model was coupled with a 2-dimensional Lagrangian particle-tracking program to simulate passive transport of these planktonic particles. Modelling analysed the separate and combined effects of the region's principal hydrodynamic forces of tide, wind and the Leeuwin Current. Model runs simulated a $30 \mathrm{~d}$ period to recreate residual transport on time scales encompassing early snapper development prior to settlement. Hydrodynamic conditions during winter were tidally dominated and exhibited minimal residual flows. Eggs and larvae were retained within residual eddies that were coincident with the 4 main spawning areas. No connectivity between these areas was observed. The results provided further evidence of the existence of a number of proximate but geographically discrete spawning populations of snapper in Shark Bay waters. Hydrodynamic retention provides a mechanism that partly explains existing data indicating that snapper stock-structure in the region is complex. Such information is fundamental to determining the most appropriate geographic scale at which local snapper populations should be managed.
\end{abstract}

KEY WORDS: Eddies - Ichthyoplankton surveys · Leeuwin Current $\cdot$ Numerical hydrodynamic modelling $\cdot$ Pagrus auratus $\cdot$ Shark Bay $\cdot$ Stock structure

Resale or republication not permitted without written consent of the publisher

\section{INTRODUCTION}

Across their geographic range, many marine species are divided into reproductively isolated, self-recruiting populations. Understanding the population structure of exploited species and the spatial distribution of individual harvested stocks is fundamental to stock assessment and the implementation of effective fisheries management (Ryman \& Utter 1987, Clark 1990, Begg et al. 1999). Critical here, is the degree of connectedness between local populations, i.e. whether they are primarily sustained by recruitment from local production (and therefore relatively closed) or substantially from external sources (and therefore relatively open) (Warner \& Cowen 2002). Because many marine fish species have bipartite life cycles, the distribution of individual stocks is determined by the dispersal of eggs and larvae, and the vagility of the post-settlement stages (Harden Jones 1968, Sinclair 1988, Bakun 1996, Bradbury \& Snelgrove 2001). There is mounting evidence that some larvae use a range of behaviours in response to oceanographic conditions that can influence their dispersal (Bakun 1996, Jenkins et al. 1999, Kingsford et al. 2002, Sponaugle et al. 2002). However, it is likely that for many species, dispersal of eggs and younger larvae is essentially passive (Okubo 1994, Bradbury \& Snelgrove 2001). The spatiotemporal distribution of these earliest stages therefore depends upon local hydrodynamic processes at the time and place of spawning and initial development (Alvarez et al. 2001). 
For marine fishes with pelagic formative stages, widespread hydrodynamic dispersal can result in genetic homogeneity over large geographic distances (Bagley et al. 1999, Dudgeon et al. 2000, Kloppmann et al. 2001). However, hydrodynamic retention of eggs and larvae, particularly in combination with spawningsite fidelity, may provide barriers to gene flow that help explain stock structure amongst populations existing in apparently 'open' environments (Bailey et al. 1997, Ruzzante et al. 1999, Stepien et al. 2000, Pogson et al. 2001, Skogen et al. 2001, Gold \& Turner 2002, Smedbol et al. 2002). Some knowledge of the hydrodynamics of the water body inhabited during the planktonic pre-settlement stages can provide useful insights into population structure, the geographic distribution of individual stocks, and recruitment dynamics of marine species.

Because of the logistical difficulties in determining dispersal directly, numerical modelling has become an important tool for understanding how hydrodynamic

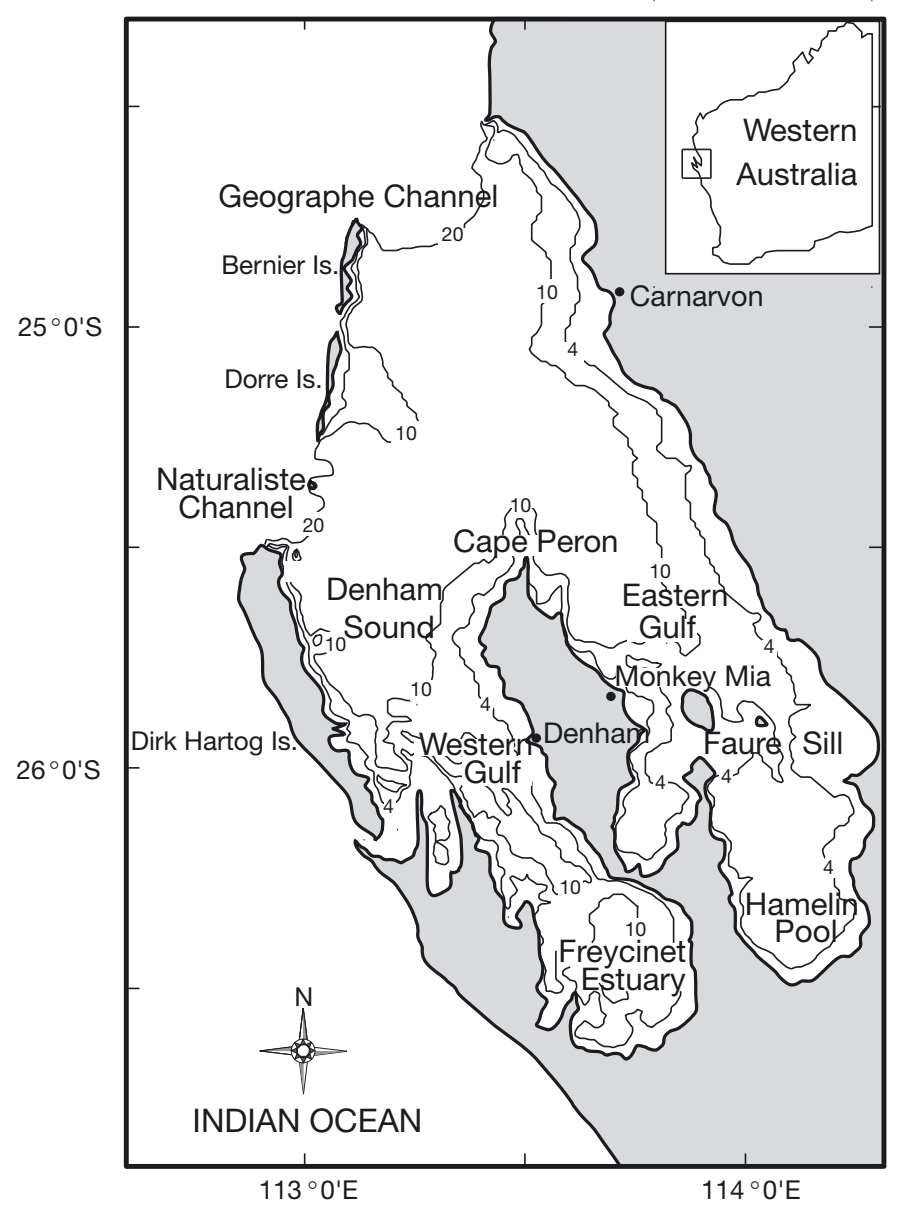

Fig. 1. Shark Bay, Western Australia, showing local bathymetry (depths, m). Western gulf includes waters of Denham Sound in the north and Freycinet Estuary in the south processes influence the transport of marine ichthyoplankton (Bartsch \& Coombs 1997, Jenkins et al. 1997, 1999, 2000, van der Veer et al. 1998, Cowen et al. 2000, Fowler et al. 2000). Selection of an adequate model requires prior knowledge of the local hydrodynamics and behaviour of the species under study. Both 2- and 3-dimensional schemes have been successfully used to model the dispersal of passive particles in marine systems. Advection of King George whiting Sillaginodes punctata larvae in South Australia and Victoria, Australia, was modelled in 3 dimensions, assuming random vertical distribution (Fowler et al. 2000, Jenkins et al. 2000), while modelling of phytoand zooplankton in Chesapeake Bay, US, used a 2-dimensional approach (Hood et al. 1999). If currents act uniformly throughout the water column, no vertical movement of planktonic organisms will significantly influence their horizontal transport. Conversely, marked differences between surface currents and those at depth can affect their horizontal movement, e.g. within coastal plumes (Roman \& Boicourt 1999) or in conditions of strong Ekman transport (Hinrichsen et al. 2001), both of which would require resolution of the vertical motion.

\section{MATERIALS AND METHODS}

Study area. Shark Bay is a large, semi-enclosed embayment, covering approximately $14000 \mathrm{~km}^{2}$, on the central coast of Western Australia (Fig. 1). The region received World Heritage status in 1991, principally for the high conservation values of its marine environment. The Bay is comprised of more open, deeper waters to the north, and shallower, Eastern and Western gulfs to the south ('Eastern Gulf' and 'Western Gulf' are not officially recognised place names, but are commonly used to refer to the collective waters on either side of the Peron Peninsula). Located on an arid coastline with minimal terrestrial runoff, the region experiences levels of evaporation greater than rainfall (Logan \& Cebulski 1970). Salinities inside Shark Bay are consistently above oceanic levels, and in the innermost reaches regularly exceed 60 (Logan \& Cebulski 1970, Burling et al. 1999). These reaches, at the southern head of the Eastern and Western gulfs (Fig. 1) are Hamelin Pool and Freycinet Estuary, respectively. Hamelin Pool exhibits higher salinities than the Freycinet Estuary, due to the effect of Faure Sill (Fig. 1), the general shallowness of its waters, and its geographic isolation from deeper waters to the north. These highly saline reaches cause a gravity-driven, bottom flow of more dense water northwards out of the gulfs. Tidal mixing creates a state of equilibrium between the mixed and stratified regions of the Bay, 
the transitions between which constitute density fronts (Logan \& Cebulski 1970, Smith \& Atkinson 1983, Burling et al. 1999). The 2 primary fronts, a semi-circular intrusion around Naturaliste Channel and a transition running southwest to northeast from Denham Sound to Carnarvon, effectively divide Shark Bay into its deeper northern and shallower southern sections. Satellite sea-surface temperature (SST) images indicate that the system has remained stable for more than 3 decades.

The physical and biological oceanography of waters offshore from Shark Bay is dominated by the Leeuwin Current, a major eastern boundary current, that flows southwards off the West coast of Australia (Lenanton et al. 1991). Recruitment to many commercially important Western Australian fisheries is affected by interannual variations in current strength and water temperature (Lenanton et al. 1991, Caputi et al. 1996) resulting mainly from El Niño/Southern Oscillation (ENSO) fluctuations (Pearce \& Phillips 1988, 1994). Shark Bay also experiences large seasonal variations in wind strength and direction. Strong southerly winds (averaging $10 \mathrm{~m} \mathrm{~s}^{-1}$ ) dominate during the austral summer (December to February), while weaker (averaging $3 \mathrm{~m} \mathrm{~s}^{-1}$ ) and more variable winds (usually SSE) occur during winter (June to August). Logan \& Cebulski (1970) and Burling et al. (1999, 2003) have provided details of the region's marine environment.

Study species. Snapper Pagrus auratus (Sparidae; known locally in Western Australia as 'pink snapper' but referred to here simply as snapper, synonymous with Chrysophrys unicolor, C. auratus, and P. major), is a long-lived, demersal species found throughout the warm temperate waters of Australia, New Zealand and Japan (Kailola et al. 1993). In Shark Bay, the species has been the basis of an important commercial fishery since the early 1900s (Moran \& Jenke 1989) and, in more recent decades, a major recreational fishery. Results of multidisciplinary research carried out over a period of more than $20 \mathrm{yr}$ suggest that the snapper population structure in the region is unusually complex at a fine spatial scale, particularly within the gulfs. From the results of allozyme-based genetics studies (Johnson et al. 1986, Whitaker \& Johnson 1998, Baudains 1999), it has been inferred that snapper in oceanic waters adjacent to Shark Bay, in the eastern gulf and in the Freycinet Estuary represent separate breeding populations, while fish in Denham Sound may be partially isolated. Whether these represent different stocks sensu stricto remains unresolved, given that interpretation of allozyme data requires some caution (Ward 2000, Hellberg et al. 2002) because (1) environmental selection has been recorded for snapper elsewhere (Smith 1979), and (2) observed differences in alleles may only reflect local environ- mental gradients (clines). However, evidence for the existence of closely adjacent but separate populations is available from numerous related studies. Tagging (Moran et al. in press), otolith trace elements and stable isotopes (Edmonds et al. 1989, 1999, Bastow et al. 2002), morphometrics (Moran et al. 1998) and lifehistory parameters, indicate little or no mixing between oceanic and gulf snapper nor between the 2 gulfs. Substantial spawning-site fidelity has been found both in oceanic and gulf waters (Moran et al. in press). The existing paradigm is that a number of proximate populations inhabit the gulfs each resident within discrete areas, in some cases separated by only tens of kilometres. Current management recognises discrete snapper stocks in (1) oceanic waters adjacent to Shark Bay, (2) the eastern gulf, (3) Denham Sound, and (4) the Freycinet Estuary. Oceanic snapper are the basis of an important commercial hook-and-line fishery, while snapper inhabiting the gulfs are the main target species for the region's important recreational fishery.

Snapper are batch-spawners (Crossland 1977, Scott \& Pankhurst 1992). In Shark Bay, they form spawning aggregations over an extended period from late autumn (April to May) through to early spring (September to October), with most spawning taking place during winter (June to August). Snapper in oceanic waters and in the northern waters of both the eastern (off Cape Peron and Monkey Mia) and western (Denham Sound) gulfs generally spawn 1 to 2 mo earlier than fish in the Freycinet Estuary. Spawning is highly localised, and in the gulfs principally occurs at the same key spawning sites each year (Jackson \& Cheng 2001). Spawning mostly takes place between midday and early evening, ca. 3 to $5 \mathrm{~m}$ below the surface in waters of 10 to $14 \mathrm{~m}$ average depth. Snapper eggs, which are positively buoyant immediately postfertilisation, become more neutrally buoyant during development (Kitajima et al. 1993). The egg incubation period is influenced by environmental conditions, particularly water temperature, with eggs estimated to hatch after ca. 20 to $30 \mathrm{~h}$ in gulf waters (Norriss \& Jackson 2002). A pelagic larval period of approximately 20 to 25 d (based on daily otolith increments, N. Tapp, pers. comm.) occurs prior to metamorphosis, settlement, and commencement of the demersal juvenile phase.

The genetic and phenotypic evidence for the existence of several reproductively isolated populations of snapper in Shark Bay has resulted from studies involving mainly sub-adults and adults, i.e. fish older than 2 or 3 yr. The potential for any mixing between these putative populations via the hydrodynamic dispersal of eggs and larvae originating from proximate (but possibly separate) spawning populations/natal areas has 
not previously been studied. Hydrodynamic retention of the ichthyoplankton in the vicinity of the main spawning areas would provide a mechanism that would preclude mixing between adjacent populations prior to settlement. The objective here was to test the hypothesis that eggs and larvae were retained in close proximity to the main snapper spawning grounds in each gulf. Using ichthyoplankton data collected between 1997 and 2000, we quantified a number of discrete egg and larval distributions that were taken to represent the main snapper spawning grounds. We then examined these distributions for any spatial overlap over the planktonic development period to test the null hypothesis of no connectivity between the spawning populations/natal areas. Hydrodynamic conditions and the consequent dispersal of planktonic particles were simulated using numerical modelling, to provide some explanation for the observed patterns in egg/ larval distributions and to determine the degree of connectivity between the spawning populations.

Ichthyoplankton surveys. Surveys were undertaken in both gulfs during winter (June to August) each year between 1997 and 2000, principally to facilitate the estimation of snapper egg production for stockassessment purposes (Jackson \& Cheng 2001). Sampling from 8 and $9 \mathrm{~m}$ research vessels employed double-oblique tows of a bongo-net (each net mouth $60 \mathrm{~cm}$ in diameter, net mesh $500 \mu \mathrm{m}$ ) during the daytime at pre-determined locations in a grid-like pattern. A General Oceanics flowmeter was fitted in the mouth of one net to measure the volume of water sampled at each tow location. Ichthyoplankton samples were fixed at sea in $5 \%$ buffered formaldehyde.

Samples collected each year were subsequently sorted in the laboratory, when snapper eggs were identified, counted and classified into development stages based on their internal morphology (Norriss \& Jackson 2002). Eggs were attributed a median age (hours) based on their stage and empirical relationships between egg development time, water temperature and salinity (Norriss \& Jackson 2002). For samples collected in 2000 only, snapper larvae were identified and counted with reference to published descriptions (Cassie 1956, Neira et al. 1998). Ichthoyplankton abundances were corrected for the volume of water filtered and expressed as number of individuals $100 \mathrm{~m}^{-3}$.

The geographic distributions of snapper eggs and larvae (samples in 2000 only) were summarised by mapping their centroids of distribution under the assumption that the data followed bivariate normal distributions in latitude and longitude. Centroids and the respective variance-covariance matrices (Kendall $\&$ Picquelle 1990) were computed for; (1) eggs $<2 \mathrm{~h}$ old, (2) eggs $>24 \mathrm{~h}$ old and (3) all larvae. Ellipsoids were drawn around each centroid to represent the $95 \%$ confidence intervals from the rotated axes. Spatial displacement and directional movement of the centroids was estimated using the 'ribbons formulae' (National Mapping Council of Australia 1972, Cheng \& Chubb 1998). Hotelling's $T^{2}$ test (Seber 1983) was used to test for centroid movement, assuming unequal dispersion matrices.

Hydrodynamic surveys. A conductivity-temperature-density (CTD) probe was employed during the ichthyoplankton surveys conducted in 2000 (for a description of the probe and sensors see Fodzar et al. 1985). The CTD was deployed vertically and recorded data at a rate of $1 \mathrm{~Hz}$ as it descended at $1 \mathrm{~m} \mathrm{~s}^{-1}$ to the sea floor. Deployments of the CTD were completed at a subset of the ichthyoplankton survey sites in the eastern gulf, in Denham Sound, and at additional locations in the western gulf (Fig. 2). Additional CTD data for these waters were obtained from previous hydrodynamic surveys in 1995. Salinity was calculated using the practical salinity scale 1978 (PSS78) (Lewis 1980, Pickard \& Emery 1990).

Numerical modelling. Snapper eggs and larvae were considered as passive particles distributed within the surface layer. This simplified 2-dimensional approach was deemed appropriate as CTD casts indicated homogeneity throughout the water column, implying a uniform flow regime across all depths. Note that the effect of wind will alter these conditions, resulting in higher velocities at the surface; however, the modelled particles will be subject to such winds, as they are simulated in the surface layer, and therefore the results will accurately reflect the affect of wind on the surface.

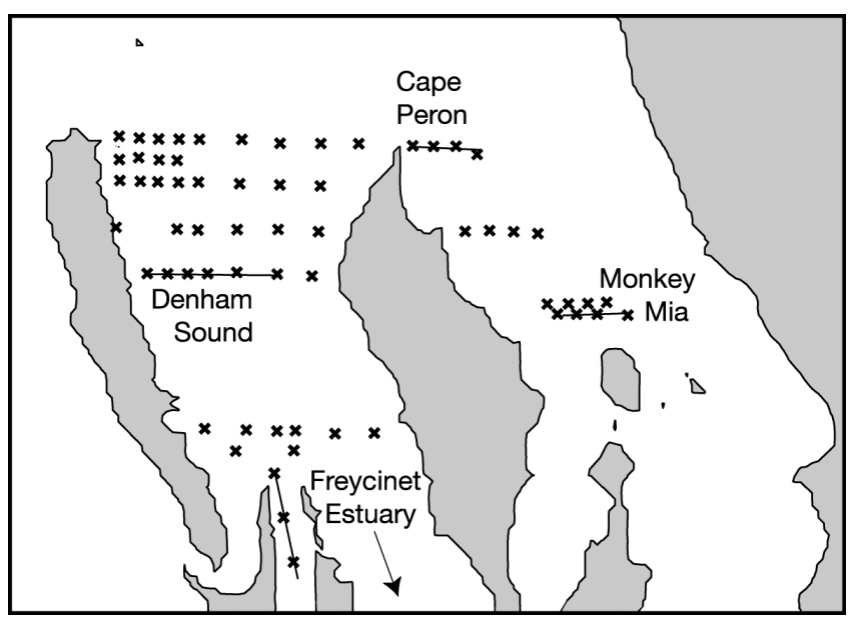

Fig. 2. CTD transects completed during ichthyoplankton surveys in June and July 2000. Transects labelled are those used in the temperature-salinity diagram (Fig. 5). (x) locations of CTD casts 
Particle-tracking was based on a simple Lagrangian framework with displacements driven by the following equations:

$$
\begin{aligned}
& \frac{\mathrm{d} x}{\mathrm{~d} t}=U+u^{\prime} \\
& \frac{\mathrm{d} y}{\mathrm{~d} t}=V+V^{\prime}
\end{aligned}
$$

where $U$ and $V$ represent the corresponding $x$ and $y$ advective velocities. Similarly, $u^{\prime}$ and $V^{\prime}$ represent turbulent velocity fluctuations in $x$ and $y$.

Advective velocities were generated using the 'Hamburg Shelf ocean model' (HAMSOM) in barotropic mode. HAMSOM is a 3-dimensional primitive equation model initially developed by Backhaus (1985) for simulations of the North Sea, and uses semi-implicit and finite-difference schemes (Backhaus 1985, Stronach et al. 1993). HAMSOM has been successfully applied to coastal and estuarine systems worldwide (Backhaus 1985, Stronach et al. 1993, Pattiaratchi et al. 1996, van der Veer et al. 1998, Ranasinghe \& Pattiaratchi 1999), and was modified for Shark Bay by Burling et al. (2003).

HAMSOM assumes hydrostatic pressure and the Boussinesq approximation. Hydrostatic pressure assumes that pressure at a given depth is only a function of atmospheric pressure and the depth of the water above that point. The Boussinesq approximation further assumes that changes in inertia, as caused by density variations, are small and could be neglected. HAMSOM also uses a kinematic boundary condition at the surface and a quadratic stress condition at the bottom. Tidal forcing was simulated by changing surface elevations along model boundaries and wind data were applied across the entire model grid. The Leeuwin Current was introduced as an inflow from the northern boundary. Inputs to the model included $\mathrm{M}_{2}$, $\mathrm{S}_{2}, \mathrm{~K}_{1}$ and $\mathrm{O}_{1}$ tidal components (lunar semi diurnal, solar semi diurnal, lunisolar diurnal and lunar diurnal, respectively), wind data, and a southerly flowing Leeuwin Current of $0.1 \mathrm{~m} \mathrm{~s}^{-1}$ (Burling et al. 2003). Other parameters included a standard bottom-friction factor of 0.0025 (Pugh \& Vassie 1976) and a Coriolis factor of $6.3 \times 10^{-5} \mathrm{~s}^{-1}$. The Coriolis factor is used to determine the Coriolis acceleration of any moving object and is a set function of the angular velocity of the earth and the local latitude. The model grid was $160 \times 94 \times 10$, with a $2 \mathrm{~km}$-square horizontal resolution and a variable vertical resolution of 10 layers. The model time step was 1 min and velocities were output at hourly intervals.

Turbulent velocities $u^{\prime}$ and $v^{\prime}$ were generated using a random-walk technique with a normally distributed, random perturbation, ' $r$ ', scaled by the magnitude of the diffusive velocity. Velocity was then calculated using the relationship

$$
v^{\prime}, u^{\prime}=r\left(\frac{K}{\mathrm{~d} t}\right)^{\frac{1}{2}}
$$

where $K$ is the horizontal diffusivity $\left(\mathrm{m}^{2} \mathrm{~s}^{-1}\right)$ and $\mathrm{d} t$ is the calculation time step.

The horizontal diffusivity, used both for turbulent velocity computations as well as HAMSOM input, was calculated using the results of Okubo (1974), whose findings have been verified by the field studies of Murthy (1976) and Lawrence et al. (1995). Horizontal diffusivity was calculated as a function of length scale:

$$
K=\left(1.1 \times 10^{-4}\right) L^{1.33}
$$

where $L$ is the minimum grid resolution of $2 \mathrm{~km}$, which results in a $K$ of $2.7 \mathrm{~m}^{2} \mathrm{~s}^{-1}$. This formulation of horizontal diffusivity simulates the forcing mechanisms that operate on smaller, unresolved time and length $(<2 \mathrm{~km})$ scales.

Using the numerical framework described, 7 different hydrodynamic scenarios were simulated, each with a $30 \mathrm{~d}$ run time. A single particle was released from 4 separate release points each hour during the simulations to allow for temporal variation in tidal conditions. The locations of these release points were taken to represent the approximate centres of the 4 principal snapper spawning areas in the gulfs, each of which contained a number of individual snapper spawningsites. The locations of these were determined by the higher densities (>50 eggs $100 \mathrm{~m}^{-3}$ ) of the youngest eggs (i.e. $<2 \mathrm{~h}$ old) collected from ichthyoplankton surveys between 1997 and 2000 (Fig. 3). The spawning areas are referred to as Cape Peron, Monkey Mia, Denham Sound and Freycinet Estuary $(a, b, c, d$, respectively, in Fig. 3). Although the focus of this study was the gulf spawning populations, an important spawning area for the oceanic stock is known to exist at the northern end of Dirk Hartog Island in the Naturaliste Channel (see 'Results').

Forcing inputs to the model included actual and idealised conditions (Table 1). The first 3 simulations

Table 1. Summary of model runs. All simulations included tidal forcing; those with additional forcing from Leeuwin Current and wind are described. ni: not included

\begin{tabular}{|lcc|}
\hline Model run & Leeuwin current & Wind \\
\hline t06 & $\mathrm{ni}$ & $\mathrm{ni}$ \\
lc07 & $0.10 \mathrm{~m} \mathrm{~s}^{-1}$ & $\mathrm{ni}$ \\
w05 & $0.10 \mathrm{~m} \mathrm{~s}^{-1}$ & $5 \mathrm{~m} \mathrm{~s}^{-1}$ southerly \\
jun08 & $0.10 \mathrm{~m} \mathrm{~s}^{-1}$ & June 1998 data \\
jul09 & $0.10 \mathrm{~m} \mathrm{~s}^{-1}$ & July 1999 data \\
aug10 & $0.10 \mathrm{~m} \mathrm{~s}^{-1}$ & August 2000 data \\
run11 & $0.10 \mathrm{~m} \mathrm{~s}^{-1}$ & January 200 data \\
\hline
\end{tabular}




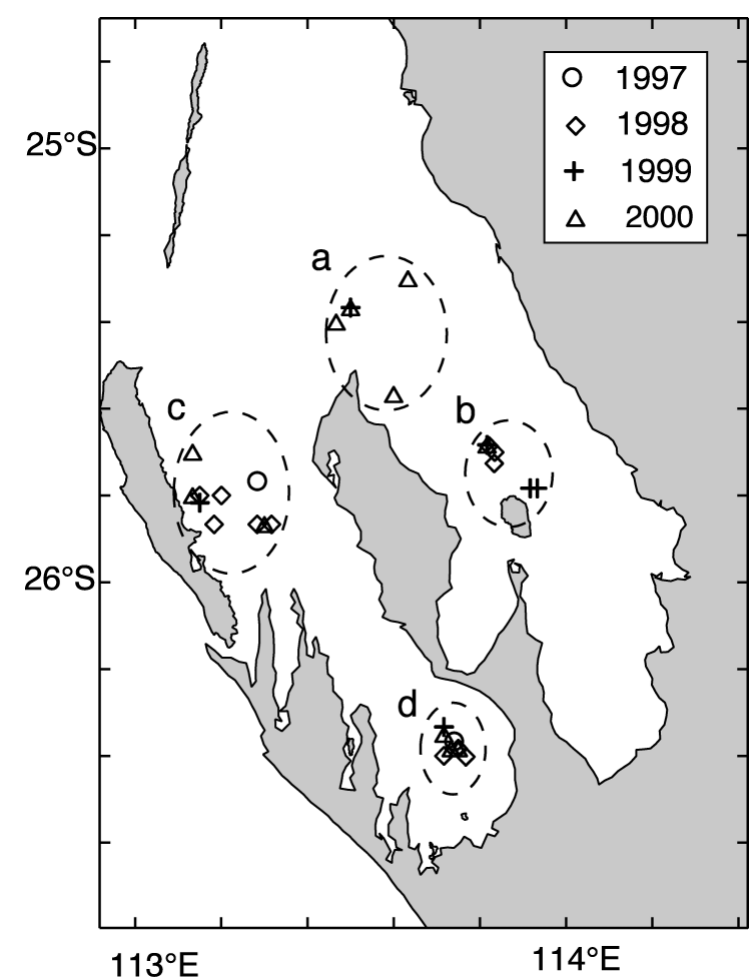

Fig. 3. Model domain for particle-tracking, determined by locations at which highest densities of Pagrus auratus eggs $<2 \mathrm{~h}$ old were collected during surveys in 1997 to 2000. Dashed circles: 4 main snapper spawning-areas: Cape Peron (a), Monkey Mia (b), Denham Sound (c) and Freycinet Estuary (d). Particlerelease points were located within each of these 4 areas

isolated the major hydrodynamic forces, including idealised wind conditions, for a controlled comparison. The remaining simulations included all the major hydrodynamic forces and observed wind data for Denham. In 3 model runs, we used data typical for months when the ichthyoplankton surveys were carried out, i.e. June, July and August, while in the fourth run we used data typical for January for seasonal comparison
(Table 1). Wind data from the Carnarvon meteorological station were used, as data from Denham were consistently lower in magnitude, probably due to sheltering effects of the local topography. Comparisons of wind rosettes (data not shown) for the period 1997 to 2000 showed good monthly correlation between years.

\section{RESULTS}

\section{Ichthyoplankton surveys}

Although only the results from 2000 are presented here, the patterns of egg and larval distributions were similar to those found in previous years (1997 to 1999). In 2000, a total of 305 plankton tows were carried out between June and August across the gulfs (Fig. 4). The highest densities of the youngest eggs were in close proximity to the known spawning sites, the locations of which were confirmed in most cases by the concomitant capture of spawning snapper. These spawning sites were located (Fig. 4) within the 4 broad spawning areas (see 'Materials and methods - Numerical modelling'), i.e. off Cape Peron, northeast of Monkey Mia, in Denham Sound, and in the Freycinet Estuary. Older eggs and larvae were still found within these broad spawning areas, but had to some extent dispersed away from the actual spawning sites. Concentrations of eggs and larvae were found off the northern tip of Dirk Hartog Island, known to be an important spawning area for oceanic snapper that is regularly targeted by commercial operators (Moran et al. 1998). This clearly indicated some overlap in the distribution of eggs and larvae derived from the oceanic and Denham Sound spawning populations.

The centroids of distribution representing the 4 main spawning areas all showed statistically significant movement with increasing development of the eggs/larvae (Table 2), with the exception of older eggs and larvae in the spawning area off Cape Peron.

Table 2. Distance and direction of movement of centroids representing each spawning area. Hotelling's $T^{2}$-test statistics in bold are significant $(\mathrm{p}<0.05)$

\begin{tabular}{|c|c|c|c|c|c|c|c|}
\hline \multirow[t]{2}{*}{ Spawning area } & \multirow[t]{2}{*}{ Age } & \multicolumn{2}{|c|}{ Distance moved by centroid (km) } & \multicolumn{2}{|c|}{ Direction of movement $\left({ }^{\circ}\right)$} & \multicolumn{2}{|c|}{$T^{2}$ statistic } \\
\hline & & Eggs $>24 \mathrm{~h}$ & Larvae & Eggs $>24 \mathrm{~h}$ & Larvae & Eggs $>24 \mathrm{~h}$ & Larvae \\
\hline \multirow[t]{2}{*}{ Cape Peron } & Eggs < $2 \mathrm{~h}$ & 12.44 & 12.72 & 231 & 227 & 0.00 & 0.00 \\
\hline & Eggs $>24 \mathrm{~h}$ & & 0.97 & & 151 & & 0.15 \\
\hline \multirow[t]{2}{*}{ Monkey Mia } & Eggs $<2 \mathrm{~h}$ & 4.89 & 2.65 & 284 & 136 & 0.00 & 0.00 \\
\hline & Eggs $>24 \mathrm{~h}$ & & 7.25 & & 114 & & 0.00 \\
\hline \multirow[t]{2}{*}{ Denham Sound } & Eggs $<2 \mathrm{~h}$ & 4.51 & 6.50 & 106 & 356 & 0.00 & 0.00 \\
\hline & Eggs $>24 \mathrm{~h}$ & & 9.16 & & 326 & & 0.00 \\
\hline \multirow[t]{2}{*}{ Freycinet Estuary } & Eggs $<2 \mathrm{~h}$ & 3.53 & 4.18 & 159 & 190 & 0.00 & 0.00 \\
\hline & Eggs $>24 \mathrm{~h}$ & & 1.96 & & 248 & & 0.00 \\
\hline
\end{tabular}



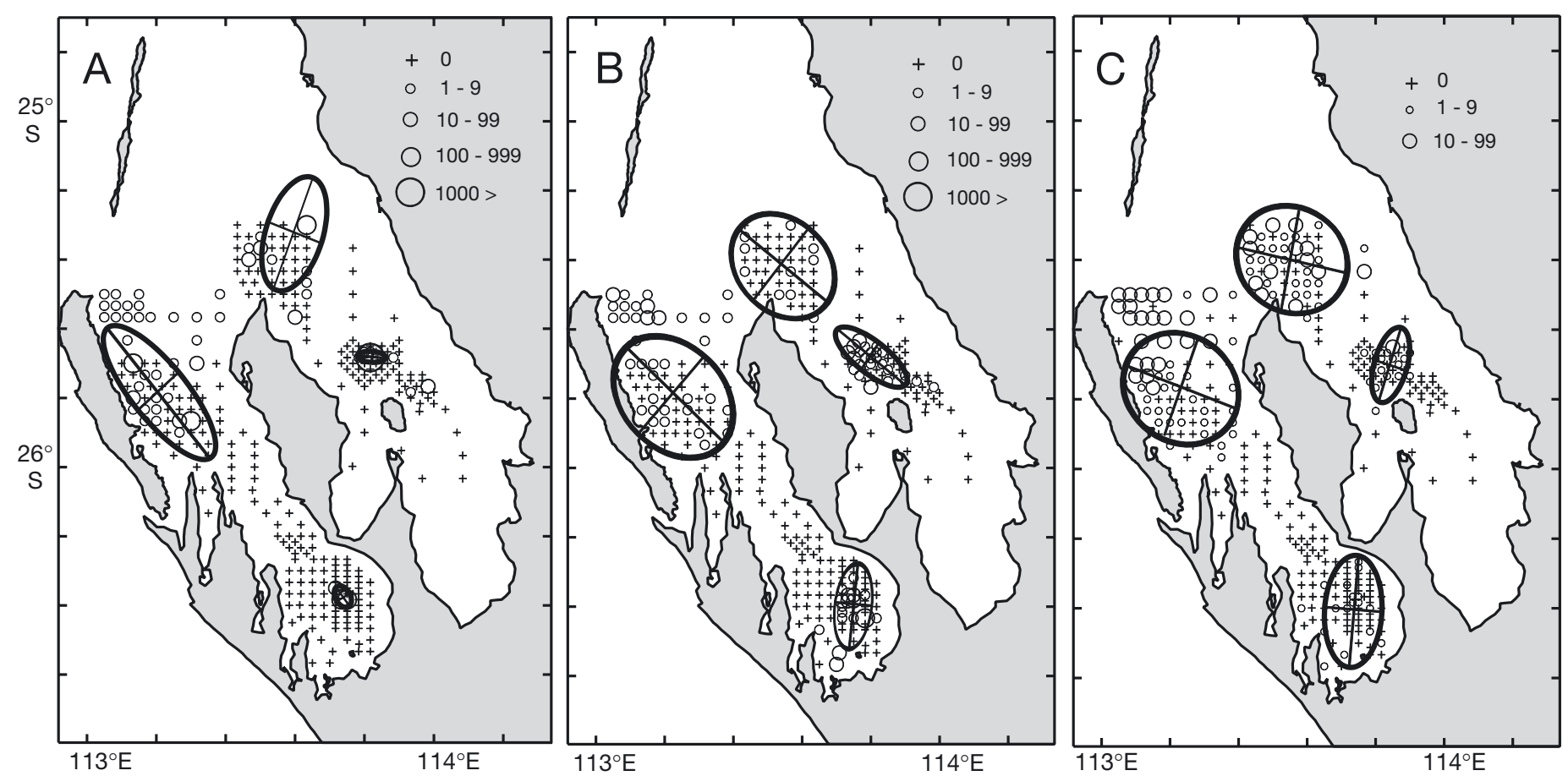

Fig. 4. Pagrus auratus. Egg and larval distributions during ichthyoplankton surveys in 2000. (A) Eggs $<2 \mathrm{~h}$ old; (B) eggs $>24 \mathrm{~h}$ old; (C) all larvae. Units in keys are numbers $100 \mathrm{~m}^{-3}$. Ellipsoids represent $95 \%$ confidence intervals from rotated axes of the centroids of distribution for snapper spawning areas defined in Fig. 3

However, given that the distances moved by each centroid were mostly less than $10 \mathrm{~km}$, the results were interpreted as biologically insignificant in the context of this study. The null hypothesis of no spatial connectivity between the main spawning areas was therefore accepted with the exception of the spawning grounds in Denham Sound and oceanic waters in the Naturaliste Channel, where there seems to be some spatial overlap.

\section{Hydrodynamic surveys}

The marked differences in water temperature and salinity characteristics between the 4 areas clearly showed that Shark Bay contained a number of separate water masses (Fig. 5). Hydrodynamic surveys were not conducted in the Freycinet Estuary in 2000; conditions found along the most southerly transects in Denham Sound (Fig. 2) were assumed to be representative of those further south. Overall, the system exhibited differences in temperature of almost $6^{\circ} \mathrm{C}$ and salinity of more than 6. In the western gulf, Denham Sound and Freycinet Estuary data were collected approximately $35 \mathrm{~km}$ apart and showed a difference in temperature of almost $6^{\circ} \mathrm{C}$, and in salinity of almost 5. In the eastern gulf, Cape Peron and
Monkey Mia sites were approximately $30 \mathrm{~km}$ apart and exhibited similar temperatures but a salinity difference of 4 .

Waters were generally vertically mixed, with some stratification apparent in the northern region of the western gulf in the vicinity of the Naturaliste Channel frontal system. Conditions in the gulfs were probably dominated by diffusive-mixing processes such as those known to occur across Faure Sill (Burling et al. 1999). This implies that, irrespective of where snapper eggs and larvae were distributed within the water column, they would be subject to the same hydrodynamics and therefore similar advection. Thus, the 2-dimensional model used here adequately represented the local hydrodynamic conditions.

\section{Numerical modelling \\ Surface residual flows}

The predicted residual currents were initially analysed at the local scale in the areas of higher egg and larval abundance. For tide-only runs, $30 \mathrm{~d}$ tidal residual velocity plots were overlaid with ichthyoplankton data to relate velocity structure to the observed patterns of egg and larval distributions. A 
series of circulatory flows with stagnant cores (eddies), probably reflecting the influence of the complex local topography, were identified in all 4 areas of interest.

Around Cape Peron there was strong flow convergence, accelerated by the topography, with water moving northwards out of each gulf either side of the Peron Peninsula (Fig. 6A). North of the Cape, the residual flow decreased and separated into an eastern eddy and a northwestern current. The model results indicate that eggs and larvae are advected from the eastern gulf, northwards through a convergent zone, towards a stagnant eastern region, with the possible loss of some eggs and larvae to waters to the northwest under certain conditions. In the Monkey Mia region (Fig. 6B), the southerly portion of the same velocity path initially headed westwards and then turned northwards towards Cape Peron, representing a possible hydrodynamic link between the 2 areas. With maximal residual velocities of $\sim 5 \mathrm{~cm} \mathrm{~s}^{-1}$, passive advection from Monkey Mia to Cape Peron (approximately $50 \mathrm{~km}$ apart) via this pathway would take a minimum of $12 \mathrm{~d}$. To the southeast, flow accelerated across Faure Sill, diverged around Faure Island, and converged again to form the main eddy in the Monkey Mia region.

In the western gulf, in Denham Sound, eggs and larvae were concentrated in the modelled regions of peripheral, high-velocity flow (Fig. 6C). Material origi-

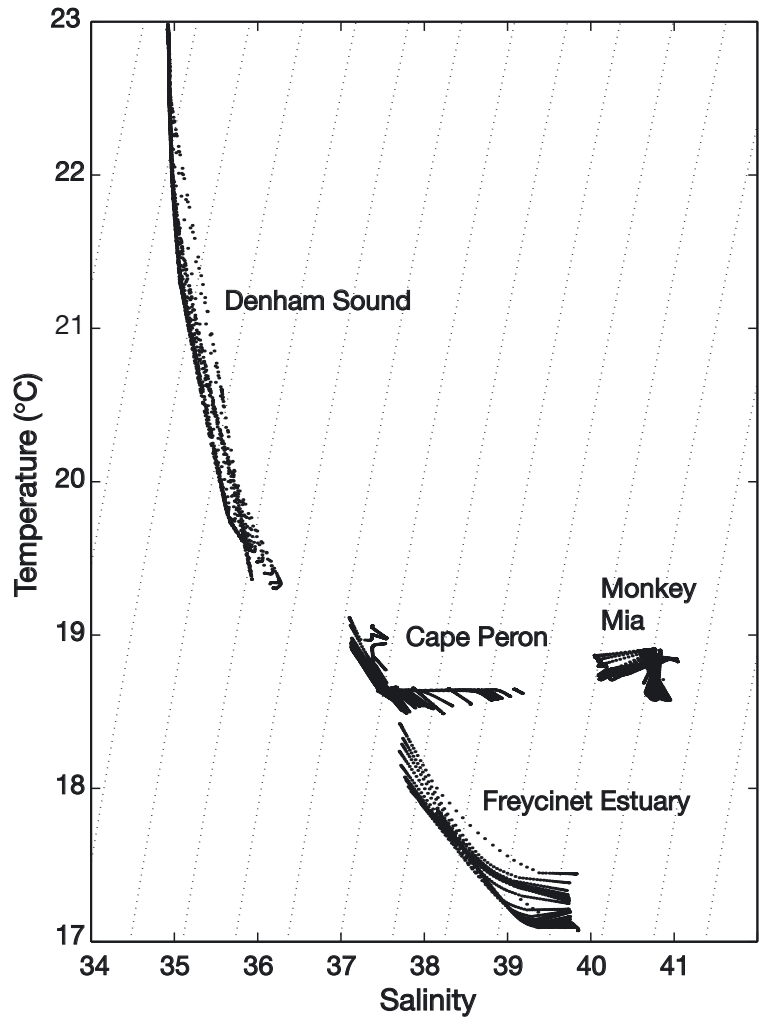

Fig. 5. Temperature-salinity signatures for Shark Bay indicating unique (non-overlapping) water bodies in 4 main snapper Pagrus auratus spawning areas
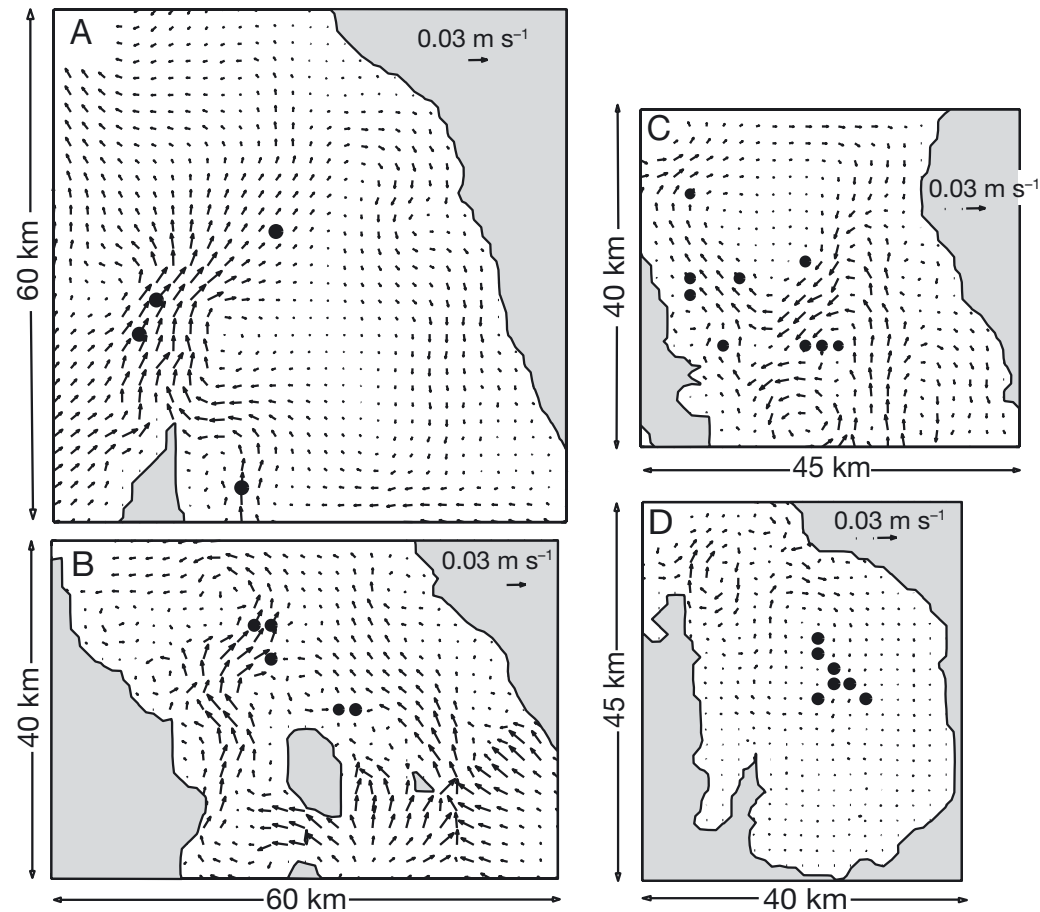

Fig. 6. Predicted surface residual currents plotted at 4 main snapper Pagrus auratus spawning areas. (A) Cape Peron; (B) Monkey Mia; (C) Denham Sound; (D) Freycinet Estuary. (•) Locations at which highest densities of younger eggs were found nating in the southeast would be moved northwest via 2 counter-rotating systems before slowing at the northern margin of an eddy. The Freycinet Estuary likewise contained a circular flow encompassing the locations of higher egg and larval abundance (Fig. 6D). However, velocities were generally low, suggesting that the entire southern section of the western gulf was mostly free of residual transport.

Hydrodynamic processes on a broader scale were examined using residual current plots of the entire Shark Bay system. The tide-only run (Fig. 7A) showed low residual flows in gulf waters to the south and stronger flows through the Naturaliste Channel, along the inside of Bernier and Dorre Islands, and off Cape Peron. Addition of the Leeuwin Current (Fig. 7B) appeared to have minimal effect in the gulfs, although it did dampen residual flows in northern waters, possibly providing a retention mechanism for eggs and larvae north of Cape Peron. This dampening ef- 

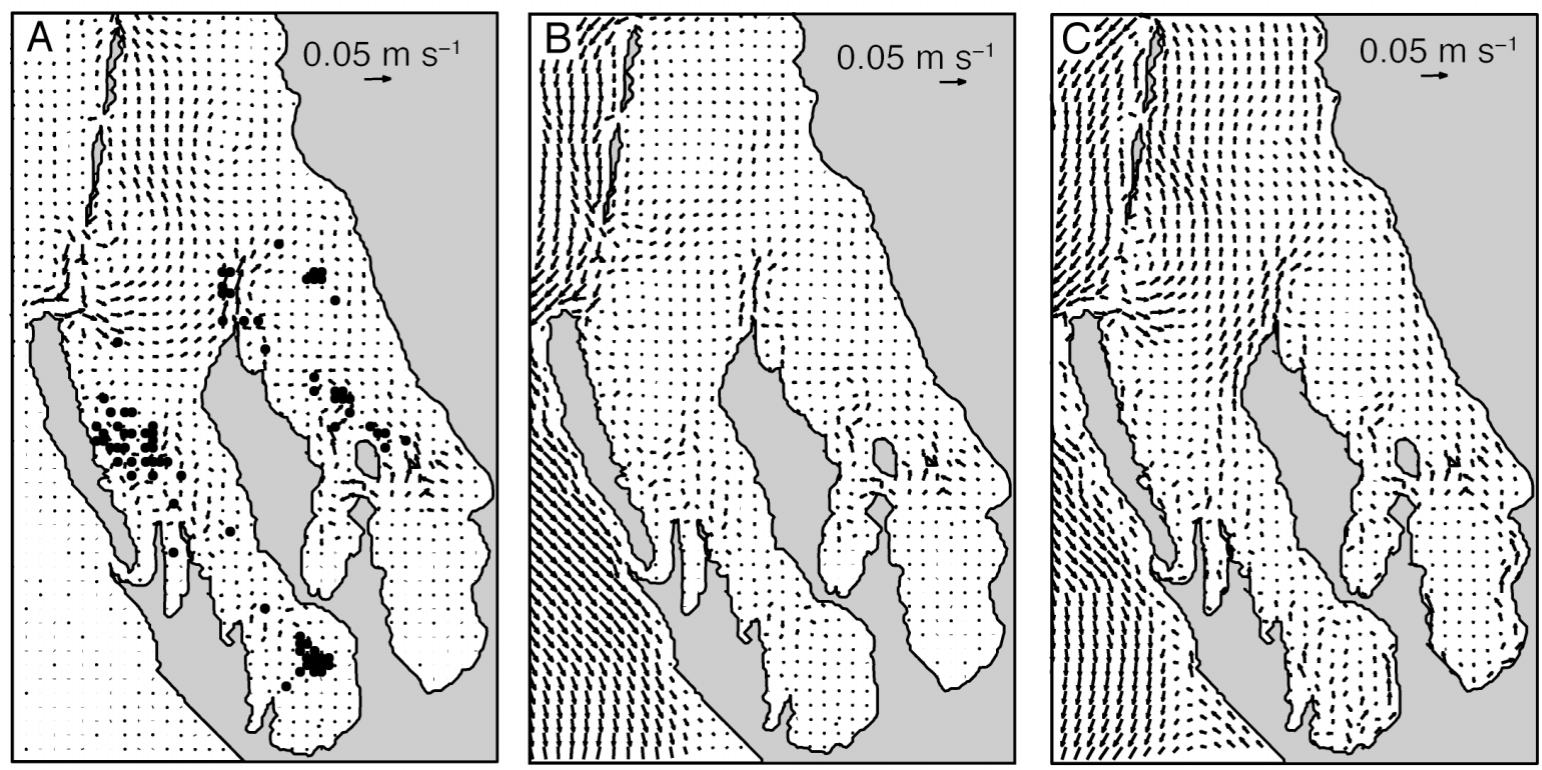

Fig. 7. Predicted surface residual currents for whole of Shark Bay under varying hydrodynamic conditions. (A) Residual current from model run including tidal forcing only (Run t06), including locations of highest densities of younger eggs (•); (B) residual currents from run including both tidal forcing and additional forcing from Leeuwin Current (Run lc07); (C) residual currents from run including all forces combined (Run w05)

fect was moderated by the addition of a southerly wind that altered conditions in northern Shark Bay from tidally-driven to wind-driven (Fig. $7 \mathrm{C}$ ). Gulf conditions were only minimally altered by wind although flow velocities increased along the shores of both Hamelin Pool and the Freycinet Estuary. This opened possible advection pathways between Hamelin Pool and north of Cape Peron. Water in Denham Sound also appeared to flow northwards along the eastern shore, again indicating possible wind-driven connectivity with Cape Peron. Overall, the hydrodynamic systems in both gulfs were tidally-dominated.

\section{Particle tracking}

Particles released in each of the simulations verified the behaviour predicted by the surface residual currents. Under run conditions of tide-only, particles in all areas except Cape Peron remained inside the localised areas of cyclic residual flow (Fig. 8A). Although some particles released at Cape Peron were entrained in an eddy to the east, they were not retained to the same extent as particles released in the gulfs (Fig. 8B). Introduction of the Leeuwin Current had very little influence on particles in the regions of Monkey Mia, Denham Sound, and the Freycinet Estuary (Fig. 8C). However, it dampened the northerly residuals off Cape Peron, with the same propagation into the eastern eddy, but greatly decreased advection northwards. A constant $5 \mathrm{~m} \mathrm{~s}^{-1}$ wind from the south advected parti- cles from Denham Sound up the eastern shore via a northerly-flowing path (Fig. 8D). The Freycinet Estuary remained isolated despite an increase in local velocities. Particles from Monkey Mia were advected further eastwards, but did not reach the northerly flow along the eastern shore as in the residual plot.

Model runs using observed wind data showed the same retention patterns as the generic model. Throughout the winter (June to August), the 4 particlerelease locations in the gulfs exhibited very little interaction with northern Shark Bay (Fig. 9A-C). Cape Peron particles responded to the dampening effect of the Leeuwin Current in June and July but, with increased winds in August, moved northwards into the high residual regions to the east of Bernier and Dorre Islands (Fig. 9C). Similarly, in June and July a clockwise eddy was maintained in Denham Sound, while in August the increased wind caused some entrainment along the eastern shoreline, advecting particles towards Cape Peron. During summer (January), particles from each location followed the advection pathways seen in the residual-current plots (Fig. 6), with the exception of Freycinet Estuary which again remained isolated.

\section{DISCUSSION}

This study investigated the potential for hydrodynamic dispersal of snapper eggs and larvae in the Gulfs of Shark Bay to provide some insight into local 

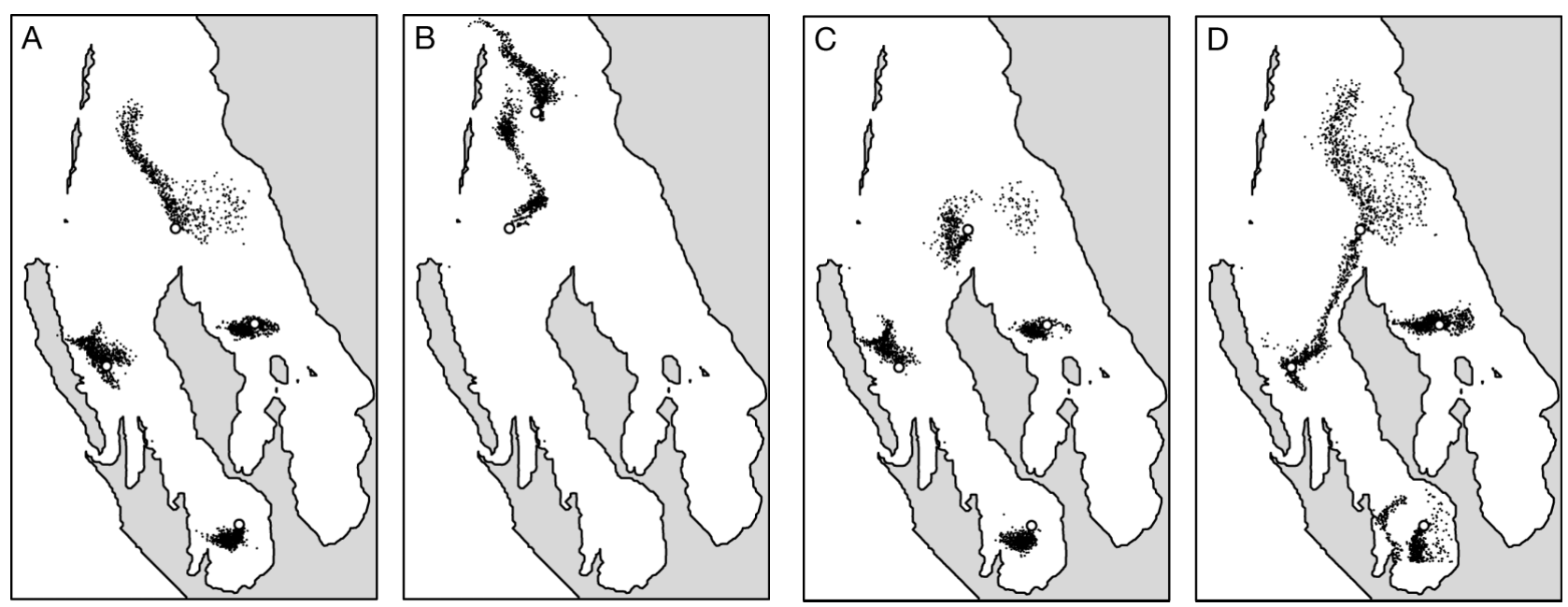

Fig. 8. Particle-tracking results for model run of $30 \mathrm{~d}$ duration, 1 particle released $\mathrm{h}^{-1}$. (O) particle-release points. (A) Model results from tidal forcing only run (t06) in areas where youngest eggs were found; (B) same model run with particles released farther north in higher residual-flow paths; (C) same release points as (A), but including Leeuwin Current (Run lc07), (D) same release points but including combination of tide, Leeuwin Current and wind (Run w05)

snapper population dynamics during the early lifehistory stages prior to settlement. Low levels of mixing between apparently separate snapper populations living in adjacent waters bodies have been inferred from previous genetic and phenotypic studies (Johnson et al. 1986, Edmonds et al. 1989, 1999, Moran et al. 1998, in press, Whitaker \& Johnson 1998, Baudains 1999, Bastow et al. 2002), mainly involving sub-adult and adults. Although direct measures of larval dispersal do not necessarily indicate successful mixing between populations (Bailey et al. 1997), highly localised retention of eggs and larvae originating from discrete natal areas would support the prevailing hypothesis that several reproductively isolated populations exist in these waters. Whether or not these represent differ- ent genetic stocks remains unclear; an important question from the management perspective is whether these proximate populations are self-recruiting or sustained by external production.

Ichthyoplankton surveys conducted during the winter spawning season over a 4 yr period consistently found the highest densities of the youngest snapper eggs within several well-defined spawning areas. Within each of these, which were assumed to represent the spawning grounds of separate breeding populations, those sites at which eggs less than $2 \mathrm{~h}$ old were collected in higher abundance were taken to represent individual spawning sites, on the basis that the eggs had not been transported any great distance. With the exception of the spawning grounds in Denham Sound
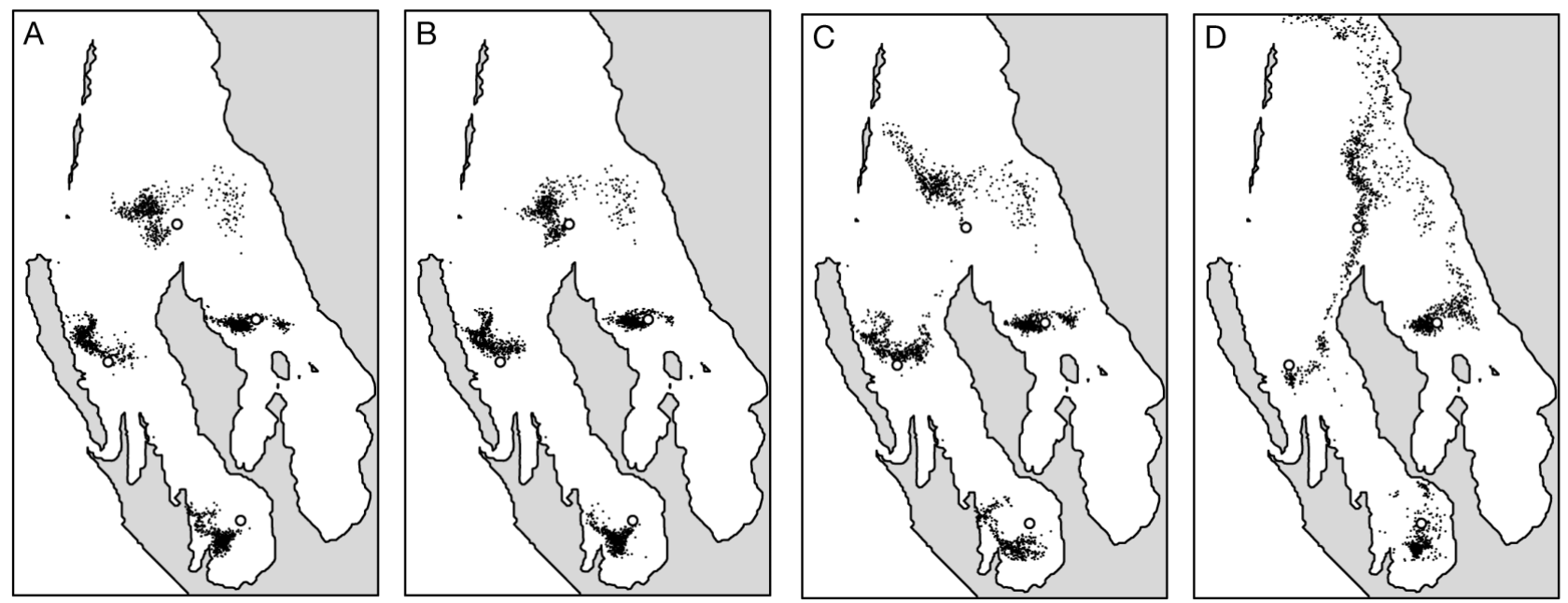

Fig. 9. Additional particle-tracking results with different forcing conditions incorporating wind data from (A) June 1998, (B) July 1999, (C) August 2000 and (D) January 2000 
and oceanic waters in the Naturaliste Channel, where there is likely to be some spatial overlap, no connectivity was found between spawning areas. This implies that the Cape Peron, Monkey Mia and Freycinet populations are reproductively isolated and probably self-recruiting, while the Denham Sound population is less so.

Hydrodynamic surveys found the waters in the vicinity of the 4 spawning areas to possess unique temperature-salinity signatures, identifying distinct water masses and implying minimal horizontal mixing. Previous studies identified tide as the primary transport mechanism in the Shark Bay gulfs (Logan \& Cebulski 1970, Burling et al. 2003). Our modelling corroborates this and suggests that tidal flows interact with local topography (Zimmerman 1978, Wolanski \& Hamner 1988) to form localised areas of convergence. These residual eddies are coincident with the main snapper spawning-grounds and provide a mechanism that would retain eggs and larvae within each natal area. The distributions of snapper ichthyoplankton observed from field surveys were consistent with this, confirming that local hydrodynamics preclude mixing of eggs and larvae between the spawning areas. Although at larger scales than those here in Shark Bay, larval retention resulting from interaction between coastal complexity and flow has been linked with marine finfish population structure elsewhere, e.g. Atlantic cod off Newfoundland (Ruzzante et al. 1999) and Pacific Ocean perch off British Columbia (Withler et al. 2001).

Although the strength of the Leeuwin Current has been linked to recruitment variation in major fisheries off Western Australia (Pearce \& Phillips 1988, 1994, Lenanton et al. 1991, Caputi et al. 1996), its influence on recruitment in gulf snapper populations appears negligible. Model simulations showed minimal penetration of the current into the shallower gulfs, with the exception of off Cape Peron where years of weaker current strength may be reflected in lower retention of eggs and larvae. We suggest that there is a strong correlation between the seasonality of snapper spawning, wind and hydrodynamic retention. Although the effect of wind was probably exaggerated here (because surface particle-tracking was used), the seasonal transitions of the system from wind-driven to tide-driven highlight patterns that could potentially affect spawning success. Snapper in the northern waters of each gulf (Cape Peron, Monkey Mia, Denham Sound) spawn mainly during months of minimum wind, i.e. June and July. Unseasonably high winds in these months would see eggs and larvae transported away from the main natal areas, thereby reducing local recruitment. In contrast, in the Freycinet Estuary where the peake in spawning occurs in August and September when winds have increased, recruitment is probably not affected, as local waters still experience low residual flows because of their geographic isolation.

The role of larval dispersal in determining whether local marine populations are open (and consequently dependent on exogenous recruitment) or relatively closed (and consequently sustained by endogenous recruitment) remains an important ecological question (Cowen et al. 2000, Swearer et al. 2002) that is largely dependent on scale (Strathmann et al. 2002, Warner \& Cowen 2002). Based on the results of our study, which was very much on a local scale, snapper populations off Cape Peron, Monkey Mia and in the Freycinet Estuary appear essentially closed, and are likely to be dependent on recruitment from local spawning. In contrast, the Denham Sound population may receive some recruitment from oceanic spawning and be therefore more open; however, the questions as to the degree to which oceanic snapper may act as a recruitment source and how any contribution may vary between years remain to be answered. Preliminary studies indicate that snapper recruitment in both gulfs, currently measured by relative abundance of $0+$ ageclass caught during annual trawl surveys, is highly variable. Although some environmentally-driven variation in mortality during the initial months after settlement is suspected, as is the case with Pagrus auratus in New Zealand (Francis 1993), further research is required.

In the study area, the snapper demonstrate many characteristics that are likely to increase the probability of self-recruitment (Swearer et al. 2002), with spawning taking place at the times (winter) and locations most favourable for retention, rapid egg development (approximately $1 \mathrm{~d}$ ), and a relatively short larval duration $(<30 \mathrm{~d})$. The latter 2 factors equate to a relatively short planktonic larval duration, the most cited biological variable potentially affecting self-recruitment (Sponaugle et al. 2002). Why gulf snapper spawn just where they do remains unclear, with no obvious habitat feature common to all spawning sites other than the hydrodynamic characteristics identified in this study. Site-selection may be some adaptation to maximise larval feeding potential, as the localised areas of convergence coincident with the spawning grounds are probably waters of relatively higher productivity within a marine environment that in general receives a limited nutrient input (Atkinson 1987). Evidence suggests that snapper spawning activity is greatest during the periods of larger tides, and therefore maximum retention, i.e. around the new moon and to some extent full moon (G. Jackson unpubl.). Overall, the behaviour demonstrated by the snapper adds support to the view proposed by Strathmann et al. (2002) that selection in non-migratory species may 
favour recruitment to the same environment as that inhabited by adults.

Evolution of the metapopulation theory has seen, in some recent cases involving marine fishes, relaxation of the structural requirements originally proposed by Levins (1970), resulting in the theory's inappropriate use (Smedbol et al. 2002). At first glance, it is tempting to conclude that snapper in Shark Bay demonstrate metapopulation structure. However, based on one of the essential metapopulation criteria (Smedbol et al. 2002), i.e. the presence of a number of discrete local breeding populations connected via the exchange of individuals, snapper in the gulfs do not conform to the metapopulation model, with the possible exception of the Denham Sound population that may exchange individuals with a larger, oceanic population. However, we concur with Smedbol et al. (2002) that scientists and managers should refrain from injudiciously using the metapopulation concept when making decisions about exploited fisheries. All identified subpopulations should be managed sustainably as distinct management stocks or units until metapopulation structure has been tested empirically.

This study provides further evidence of the existence of a number of proximate but discrete spawning populations of snapper in the gulfs of Shark Bay. The mechanism we have shown, i.e. hydrodynamic retention, partly explains existing data on local snapper-stock structure. The usefulness of numerical modelling, in providing an understanding of hydrodynamic processes that may result in stock separation at an early life-history stage is again demonstrated. The information obtained has relevance in the management of the recreational snapper fishery in the gulfs, where large numbers of visiting fishers target known snapper spawning-aggregations during winter, when fishing mortality can be high and highly localised. Populations with extensive larval retention are more vulnerable to recruitment over-fishing (Strathmann et al. 2002). In locally recruiting populations such as those of the snapper in the present study, excessive loss of larger (presumably older) and more productive members of the local populations through over-fishing have the potential to directly reduce recruitment. This is believed to have occurred in the eastern gulf in the mid-1990s, when over-exploitation of the main spawning aggregation north-east of Monkey Mia resulted in severe depletion of the adult stock and apparently low recruitment in subsequent years. Our results underline the need to continue to monitor and manage gulf snapper populations at an unusually fine spatial scale compared to many other marine fish stocks in Western Australian waters. Currently stock assessments and management arrangements recognise separate management units/fishable stocks in the eastern gulf, Den- ham Sound and the Freycinet estuary. Future research should be focussed on more adequately determining the genetic relationship between the region's snapper populations (using a DNA-based approach) and the extent of recruitment to Denham Sound from the oceanic stock and its annual variability.

Acknowledgements. The ichthyoplankton surveys were partly funded by the Natural Heritage Trust, Federal Government of Australia, Canberra (Fisheries Action Program Project 973720 ). The authors would like to thank the many members of staff of the Department of Fisheries Western Australia, Research and Regional Services Divisions, who assisted during the field surveys at various times between 1997 and 2000. Jeff Norriss, Helen Lulofs, Julie Murdoch, Mike Mackie, Sam Norton, Nadia Tapp, Sandy Seidel and Kate Truscott sorted the plankton samples. Dr. Henry Cheng (formerly Department of Fisheries Western Australia, now Washington State Department of Fish and Wildlife US) was responsible for the centroid analyses. Dr. Francisco Neira of the Australian Maritime College, Tasmania, provided advice on the identification of snapper larvae. We also thank Steve Wilson, Dan Gaughan, Mike Moran and 4 anonymous reviewers for their comments during the preparation of this manuscript. This work was made possible by an International Postgraduate Research Scholarship for a Masters degree at the School of Water Research at the University of Western Australia.

\section{LITERATURE CITED}

Alvarez P, Motos L, Uriarte A, Egana J (2001) Spatial and temporal distribution of European hake, Merluccius merluccius (L.), eggs and larvae in relation to hydrographical conditions in the Bay of Biscay. Fish Res 50:111-128

Atkinson MJ (1987) Low phosphorus sediments in a hypersaline marine bay. Estuar Coast Shelf Sci 24:335-347

Backhaus JO (1985) A three-dimensional model for the simulation of shelf sea dynamics. Dtsch Hydrogr Z 38:165-187

Bagley MJ, Lindquist DG, Geller JB (1999) Microsatellite variation, effective population size, and population genetic structure of vermillion snapper, Rhomboplites aurorubens, off the southeastern USA. Mar Biol 134:609-620

Bailey KM, Stabeno PJ, Powers DA (1997) The role of larval retention and transport features in mortality and potential gene flow of walleye pollock. J Fish Biol 51 (Suppl A): 135-154

Bakun A (1996) Patterns in the ocean - ocean processes and marine population dynamics, California Sea Grant, La Jolla, California

Bartsch J, Coombs S (1997) A numerical model of the dispersion of blue whiting larvae, Micromesistius poutassou (Risso), in the eastern North Atlantic. Fish Oceanogr 6: 141-154

Bastow T, Jackson G, Edmonds JS (2002) Elevated salinity and isotopic composition of fish otolith carbonate: stock delineation of pink snapper, Pagrus auratus, in Shark Bay, Western Australia. Mar Biol 141:801-806

Baudains G (1999) Population genetic structure of pink snapper (Pagrus auratus) in the eastern gulf of Shark Bay, Western Australia. Final Report to Natural Heritage Trust, Fisheries Department of Western Australia, Perth

Begg GA, Friedland KD, Pearce JB (1999) Stock identification and its role in stock assessment and fisheries management: an overview. Fish Res 43:1-8 
Bradbury IR, Snelgrove PVR (2001) Contrasting larval transport in demersal fish and invertebrates: the roles of behaviour and advective processes in determining spatial pattern. Can J Fish Aquat Sci 58:811-823

Burling M, Ivey GN, Pattiaratchi C (1999) Convectively driven exchange in a shallow coastal embayment. Contin Shelf Res 19:1599-1616

Burling MC, Pattiaratchi CB, Ivey GN (2003) The tidal regime of Shark Bay, Western Australia. Estuar Coast Shelf Sci $56: 725-735$

Caputi N, Fletcher WJ, Pearce A, Chubb CF (1996) Effect of the Leeuwin Current on the recruitment of fish and invertebrates along the Western Australian coast. Mar Freshw Res 47:147-155

Cassie RM (1956) Early development of the snapper, Chrysophrys auratus, Forster. Trans R Soc NZ 83:705-713

Cheng YW, Chubb CF (1998) Statistical analysis of the directional movement of the western rock lobster. In: Brown BJ (ed) Proc Sixth International Statistical Applications Institute Conf, Melbourne, p 9-16

Clark CW (1990) Mathematical bioeconomics, 2nd edn. Wiley, NewYork

Cowen RK, Lwiza KMM, Sponaugle S, Paris CB, Olson DB (2000) Connectivity of marine populations: open or closed? Science 287:857-859

Crossland J (1977) Seasonal reproductive cycle in the snapper Chrysophrys auratus (Forster) in Hauraki Gulf, New Zealand. NZ J Mar Freshw Res 11(1):37-60

Dudgeon CL, Gust N, Blair D (2000) No apparent genetic basis to demographic differences in scarid fishes across continental shelf of the Great Barrier Reef. Mar Bio 137: 1059-1066

Edmonds JS, Moran MJ, Caputi N, Morita M (1989) Trace element analysis of fish sagittae as an aid to stock identification: pink snapper (Chrysophrys auratus) in Western Australian waters. Can J Fish Aquat Sci 46:50-54

Edmonds JS, Steckis RA, Moran MJ, Caputi N, Morita M (1999) Stock delineation of pink snapper and tailor from Western Australia by analysis of stable isotope and strontium/calcium ratios in otolith carbonate. J Fish Biol 55:243-259

Fowler AJ, Black KP, Jenkins GP (2000) Determination of spawning areas and larval advection pathways for King George whiting in southeastern Australia using otolith microstructure and hydrodynamic modelling. II. South Australia. Mar Ecol Prog Ser 199:243-254

Fozdar FM, Parker GJ, Imberger J (1985) Matching temperature and conductivity sensor response characteristics. J Phys Oceanogr 15:1557-1569

Francis MP (1993) Does water temperature determine year class strength in New Zealand snapper (Pagrus auratus, Sparidae)? Fish Oceanogr 2:65-72

Gold JR, Turner TF (2002) Population structure of red drum (Sciaenops ocellatus) in the northern Gulf of Mexico, as inferred from variation in nuclear-encoded microsatellites. Mar Biol 140:249-265

Harden Jones FR (1968) Fish migration. Edward Arnold, London, UK

Hellberg ME, Burton RS, Neigel JE, Palumbi SR (2002) Genetic assessment of connectivity among marine populations. Bull Mar Sci 70(Suppl):273-290

Hinrichsen HH, St John M, Aro E, Grønkjær P, Voss R (2001) Testing the larval drift hypothesis in the Baltic Sea: retention versus dispersion caused by wind-driven circulation. ICES J Mar Sci 58:973-984

Hood RR, Wang HV, Purcell JE, Houde ED, Harding LW Jr (1999) Modelling particles and pelagic organisms in
Chesapeake Bay: convergent features control plankton distributions. J Geophys Res 104:1223-1243

Jackson G, Cheng YW (2001) Parameter estimation with egg production surveys to estimate snapper, Pagrus auratus, biomass in Shark Bay, Western Australia. J Agric Biol Environ Stat 6:243-257

Jenkins GP, Black KP, Wheatley MJ, Hatton DN (1997) Temporal and spatial variability in recruitment of a temperate, seagrass-associated fish is largely determined by physical processes in the pre- and post-settlement phases. Mar Ecol Prog Ser 148:23-35

Jenkins GP, Black KP, Keough MJ (1999) The role of passive transport and the influence of vertical migration on the pre-settlement distribution of a temperate, demersal fish: numerical model predictions compared with field sampling. Mar Ecol Prog Ser 184:259-271

Jenkins GP, Black KP, Hamer PA (2000) Determination of spawning areas and larval advection pathways for King George whiting in southeastern Australia using otolith microstructure and hydrodynamic modelling. I. Victoria. Mar Ecol Prog Ser 199:231-242

Johnson MS, Creagh S, Moran M (1986) Genetic subdivision of stocks of snapper Chrysophrys unicolor, in Shark Bay, Western Australia. Aust J Mar Freshw Res 37:337-345

Kailola PJ, Williams MJ, Stewart PC, Reichelt RE, McNee A, Grieve C (1993) Australian Fisheries Resources, Bureau of Resource Sciences, Canberra

Kendall AW Jr, Picquelle SJ (1990) Egg and larval distributions of walleye pollock Theragra chalcogramma in Shelik Strait, Gulf of Alaska. Fish Bull (Washington, DC) 88:133-154

Kingsford MJ, Leis JM, Shanks A, Lindeman KC, Morgan SG, Pineda J (2002) Sensory environments, larval abilities and local self-recruitment. Bull Mar Sci 70(Suppl):309-340

Kitajima C, Yamane Y, Matsui S, Kihara Y, Furuichi M (1993) Ontogenetic change in buoyancy in early stage of red sea bream. Nippon Suisan Gakkaishi 59:209-216

Kloppmann M, Mohn C, Bartsch J (2001) The distribution of blue whiting eggs and larvae on Porcupine Bank in relation to hydrography and currents. Fish Res 50:89-109

Lawrence GA, Ashley KI, Yonemitsu N, Ellis JR (1995) Natural dispersion in a small lake. Limnol Oceanogr 40: $1519-1526$

Lenanton RC, Joll L, Penn J, Jones K (1991) The influence of the Leeuwin Current on coastal fisheries of Western Australia. J R Soc West Aust 74:101-114

Levins R (1970) Extinction. In: Desternhaber M (ed) Some mathematical problems in biology American Mathematical Society, Providence, p 77-107

Lewis EL (1980) The Practical salinity scale 1978 and its antecedents. IEEE (Inst Electr Electron Eng) J Ocean Eng $5: 3-8$

Logan BW, Cebulski DE (1970) Sedimentary environments of Shark Bay, Western Australia. Mem Am Assoc Petrol Geol 13:1-37

Moran MJ, Jenke J (1989) Effects of fish trapping on the Shark Bay snapper fishery. West Aust Fish Dep Fish Res Rep 82:1-29

Moran M, Burton C, Caputi N (1998) Sexual and local variation in head morphology of snapper Pagrus auratus Sparidae, in the Shark Bay region of Western Australia. Mar Freshw Res 50:27-34

Moran M, Burton C, Jenke J (in press) Long-term movement patterns of continental shelf and inner gulf pink snapper (Pagrus auratus, Sparidae) from tagging in the Shark Bay region of Western Australia. Mar Freshw Res

Murthy CR (1976) Horizontal diffusion characteristics of Lake Ontario. J Phys Oceanogr 6:76-84 
National Mapping Council of Australia (1972) The Australian map grid, Technical Manual, Australian Government Publishing Service, Canberra

Neira FJ, Miskiewicz AG, Trnski T (1998) Larvae of temperate Australian fishes: laboratory guide to larval fish identification. University of Western Australia Press, Perth

Norriss JV, Jackson G (2002) Identifying the development stages of preserved eggs of snapper, Pagrus auratus, from Shark Bay, Western Australia. West Aust Fish Dep Fish Res Rep 142:1-28

Okubo A (1974) Some speculations on oceanic diffusion diagrams. Rapp P-V Réun Cons int Explor Mer 167:77-85

Okubo A (1994) The role of diffusion and related physical processes in dispersal and recruitment of marine populations. Coast Estuar Stud 45:5-32

Pattiaratchi CB, Backhaus J, Bassam Abu Shamleh and 5 others (1996) Applications of a three dimensional numerical model for the study of coastal phenomena in South-Western Australia. In: Mitchell B (ed) Proc Ocean-Atmos-Pac Conf, Natl Tidal Facil, Adelaide, p 282-287

Pearce AF, Phillips BF (1988) ENSO events, the Leeuwin Current, and larval recruitment of the western rock lobster. J Cons int Explor Mer 45:13-21

Pearce AF, Phillips BF (1994) Oceanic processes, puerulus settlement and recruitment of the western rock lobster Panulirus cygnus. Coast Estuar Stud 45:279-303

Pickard GL, Emery WJ (1990) Descriptive physical oceanography: an introduction, 5th edn, Pergamon Press, Oxford

Pogson GH, Taggart CT, Mesa KA, Boutilier RG (2001) Isolation by distance in the Atlantic cod, Gadus morhua, at large and small geographic scales. Evolution 55:131-146

Pugh DT, Vassie JM (1976) The tide and surge propagation off-shore on the Dowsing region of the North Sea. Dtsch Hydrogr Z 29:163-213

Ranasinghe R, Pattiaratchi CB (1999) Circulation and mixing characteristics of a seasonally open tidal inlet: a field study. Mar Freshw Res 50:281-290

Roman MR, Boicourt WC (1999) Dispersion and recruitment of crab larvae in the Chesapeake Bay plume: physical and biological controls. Estuaries 22:563-574

Ruzzante DE, Taggart CT, Cook D (1999) A review of the evidence for genetic structure of cod (Gadus morhua) populations in the NW Atlantic and population affinities of larval cod off Newfoundland and the Gulf of St Lawrence. Fish Res 43:79-97

Ryman N, Utter F (1987) Population genetics and fishery management. Washington Sea Grant Program, Seattle

Scott SG, Pankhurst NW (1992) Interannual variation in the reproductive cycle of the New Zealand snapper Pagrus auratus (Bloch \& Schneider) (Sparidae). J Fish Biol 41: 685-696

Seber GAF (1983) Multivariate observations. John Wiley \& Sons, New York

Sinclair M (1988) Marine populations - An essay on population regulation and speciation. Washington Sea Grant Program, Seattle

Editorial responsibility: Otto Kinne (Editor), Oldendorf/Luhe, Germany
Skogen MD, Monstad T, Svendsen E (2001) A possible separation between a northern and southern stock of the northeast Atlantic blue whiting. Fish Res 41:119-131

Smedbol RK, McPherson A, Hansen MM, Kenchington E (2002) Myths and moderation in marine 'metapopulations'. Fish Fish 3:20-35

Smith PJ (1979) Esterase gene frequencies and temperature relationships in the New Zealand snapper Chrysophrys auratus. Mar Bio 53:305-310

Smith SV, Atkinson MJ (1983) Mass balance of carbon and phosphorus in Shark Bay, Western Australia. Limnol Oceanogr 28:625-639

Sponaugle S, Cowen RK, Shanks A, Morgan SG and 7 others (2002) Predicting self-recruitment in marine populations: biophysical correlates and mechanisms. Bull Mar Sci 70 (Suppl):341-375

Stepien CA, Dillon AK, Patterson AK (2000) Population genetics, phylogeography, and systematics of the thornyhead rockfishes (Sebastolobus) along the deep continental slopes of the North Pacific Ocean. Can J Fish Aquat Sci 57:1701-1717

Strathmann RS, Hughes TP, Kuris AM, Lindeman KC, Morgan SG, Pandolfi JM, Warner RR (2002) Evolution of local recruitment and its consequences for marine populations. Bull Mar Sci 70(Suppl):377-396

Stronach JA, Backhaus JO, Murty TS (1993) An update on the numerical simulation of oceanographic processes in waters between Vancouver Island and the mainland: the gf8 model. Oceanogr Mar Biol Annu Rev 31:1-86

Swearer SE, Shima JS, Hellberg ME, Thorrold SR and 6 others (2002) Evidence of self-recruitment in demersal marine populations. Bull Mar Sci 70(Suppl):251-271

van der Veer HW, Ruardjj P, van den Berg, AJ, Ridderinkhof $\mathrm{H}$ (1998) Impact of interannual variability in hydrodynamic circulation on egg and larval transport of plaice Pleuronectes platessa L. in the southern North Sea. J Sea Res 39:29-40

Ward RD (2000) Genetics in fisheries management. Hydrobiologia 420:191-201

Warner RR, Cowen RK (2002) Local retention of production in marine populations: evidence, mechanisms, and consequences. Bull Mar Sci 70(Suppl):245-249

Whitaker K, Johnson MS (1998) Population genetic structure of Pagrus auratus in the western gulf of Shark Bay, Western Australia. Final Report to Natural Heritage Trust, Fisheries Department of Western Australia, Perth

Withler RE, Beacham TD, Schulze AD, Richards LJ, Miller KM (2001) Co-existing populations of Pacific ocean perch, Sebastes alutus, in Queen Charlotte Sound, British Columbia. Mar Biol 139:1-12

Wolanski E, Hamner WH (1988) Topographically controlled fronts in the ocean and their biological influence. Science 241:177-181

Zimmerman JTF (1978) Topographic generation of residual circulation by oscillatory (tidal) currents. Geophys Astro Fluid 11:35-47

Submitted: May 21, 2002; Accepted: July 15, 2003

Proofs received from author(s): December 30, 2003 